\title{
Role of Vesicular Arbuscular Mycorrhizal Inoculation of Zea mays on Heavy Metals Tolerance.
}

L. D. Shaaban, "G. H. Rabi and R. A. Metwally

Department of Botany, Faculty of Science, Zagazig University, 44519, Egypt

\begin{abstract}
7 HE STUDY evaluated the physiological responses of maize plant inoculated with vesicular arbuscular mycorrhiza (VAM) isolated from polluted site and growing in heavy metal $(\mathrm{Cd}$ or $\mathrm{Pb})$ polluted soil. Chlorophyll, soluble carbohydrate, soluble protein, nutrient elements ( $\mathrm{P}$ and $\mathrm{N}$ ) content and phosphatase activity were analyzed. The phosphatase activity in inoculated plants was significantly increased in comparison to the non-inoculated ones. In addition, the contents of $\mathrm{N}, \mathrm{P}$, chlorophyll, total soluble carbohydrates and protein were significantly increased in plants inoculated with mycorrhiza grown in heavy metal $(\mathrm{Cd}$ or $\mathrm{Pb})$ contaminated soil in comparing with the non-inoculated ones. Therefore, it can be concluded that the VAM inoculation is capable to alleviate the damage caused by heavy metal $(\mathrm{Cd}$ or $\mathrm{Pb})$ on maize plants that maintain the growth and this could be related to nutrient status offered by VAM. Isolation of heavy metal tolerant VAM fungi can be a potential biotechnical tool for inoculation of plant to enhance its heavy metal tolerance.
\end{abstract}

Keywords: Heavy metals, VAM, Zea mays, Phosphatase.

Heavy metal pollution has disastrous effect on plant productivity and threatens human and animal health (Adriano, 2001). Heavy metals accumulate in the soil and water tables and many reach to toxic levels. Contamination with heavy metals resulted from urban activity, agricultural practices and industry (Clemens, 2001). However, elevated concentrations of both essential and nonessential heavy metals in the soil can lead to toxicity symptoms and growth inhibition in most plants (Hall, 2002).

Toxic level of heavy metals can affect adversely on the number, diversity and activity of soil organisms, resulting in the selection of the most metal-resistant microorganisms. Therefore, autochthonous microorganisms isolated from polluted environments are likely to play an important role in the metal tolerance exhibited by the plants growing in contaminated soils. Fungi are known tolerate and detoxify metals by several mechanisms, including extra and intracellular precipitations, biosorption to the cell wall and sequestration (Zafar et al., 2007).

Mycorrhiza is the mutualistic symbiotic association of a specific group of soil-borne fungi with the roots of higher plants (Sieverding, 1991). Plant receives support from mycorrhizal fungi, with the help of its symbiotic association, in the

*Corresponding author: lamis shaaban@yahoo.com 
aspect of the uptake of phosphorus and other nutrients. Moreover, the mycorrhiza enhances the plant growth by increasing growth hormones, protein, and lipid and carbohydrate contents. Generally, endomycorrhizal plants are often more competitive and able to tolerate environmental stress than non-mycorrhizal plants (Tamboli and Vyas, 2012). However, the mechanisms by which VAM symbiosis influences the metabolism of host plants under heavy metal stress are not clear. Symbiotic interaction between VAM and host plants (especially during the growth) need to be studied under heavy metal stress conditions. The objective of this study was to determine the physiological responses of maize plant inoculated with VAM isolated from polluted site, grown in heavy metals $(\mathrm{Cd}$ or $\mathrm{Pb})$ polluted soil. The alkaline phosphatase and acid phosphatase activities, biomass, photosynthetic pigments, the protein, carbohydrates, phosphorus and nitrogen contents were concerned.

\section{Material and Methods}

\section{Soil Preparation}

The soil, used throughout the present study, was collected from Zagazig, Sharkia Governorate, Egypt. Soil samples were sieved (2-mm mesh size) to discard the impurities and gravels. Then, soil was sterilized by $5 \%$ formalin for 7 days to eliminate native arbuscular mycorrhizal fungi, after which soil was aerated.

\section{Plant material and growth condition}

Grains of maize (Zea mays L.), were obtained from Field Crop Research Institute, surface sterilized with $3 \%$ sodium hypochlorite for $5 \mathrm{~min}$, then thoroughly washed with sterilized distilled water. Five sterilized maize grains were sown in sterilized pots that filed with $8 \mathrm{~kg}$ sterilized soil. Pots were placed randomly in the greenhouse under natural photoperiods $(12-13 \mathrm{~h})$ and temperature of $28 \pm 4^{\circ} \mathrm{C}$. The inoculum used was collected from sludge-amended agricultural soil in Bahr El-Baqar, Sharkia, Egypt. It was extracted and then maintained as described by Gerdemann and Nicolson (1963). Isolate contained two different species of vesicular arbuscular mycorrhizal fungi, Glomus mosseae and G. clarum (Rabie et al., 2013). The inoculum consisted of crude soil, mycelia with spores, and colonized root segments from stock cultures of the corresponding VAM fungi. It was added at the rate of $80 \mathrm{~g}$ per pot at sowing. Known concentration of heavy metal solutions of $\mathrm{Cd}$ and $\mathrm{Pb}$ were prepared using

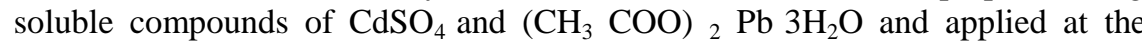
levels: $\mathrm{Cd} ; 25$ and $100 \mathrm{mg} / \mathrm{kg}$ soil and $\mathrm{Pb} ; 100$ and $1000 \mathrm{mg} / \mathrm{kg}$ soil. Pots were placed randomly in the greenhouse under natural conations.

Each treatment was replicated three times in completely randomized design. Plants were harvested after 3, 6, 9 weeks from sowing. Dry weight (DW) of shoots and roots were obtained by oven-drying at $80^{\circ} \mathrm{C}$ until constant weight.

\section{Mycorrhizal Dependency (MD)}

Mycorrhizal dependency was calculated according to Gerdemann (1975) as the following formula: MD $\%=\mathrm{DW}$ of inoculated plant at particular level of heavy metal /DW of non-inoculated plant at the same level of heavy metal $\times 100$.

Egypt. J. Bot., Vol. 55, No. 2 (2015) 
ROLE OF VESICULAR ARBUSCULAR MYCORRHIZAL INOCULATION ... 299

\section{Biochemical and physiological parameters}

Chlorophyll a, b and carotenoid contents were extracted from fresh leaf on aqueous acetone solution (85\%), and then determined according to Metzner et al. (1965). Total soluble carbohydrate content was determined according to Said and Naguib (1964). Total soluble protein was determined according Lowery et al. (1951). Nitrogen was determined by the Kjldal method as described by Jackson (1973). Total phosphorus in maize dry leaves was determined by the molybdovanado phosphate colorimetric method (Jakson, 1958).

Acid Phosphatase activity was determined using $p$-nitrophenyl phosphate disodium (PNP, $0.115 \mathrm{M}$ ) as substrate. Enzyme extract was prepared in extraction buffer containing $50 \mathrm{mM}$ citrate buffer $(\mathrm{pH} 5.3)$ for acid and $50 \mathrm{mM}$ Glycine $\mathrm{NaOH}$ buffer ( $\mathrm{pH} 10.3$ ) for alkaline phosphatase by grinding $0.5 \mathrm{~g}$ fresh root samples in $10 \mathrm{ml}$ extraction buffer. Extracts were centrifuged at $10000 \mathrm{rpm}$ for $10 \mathrm{~min}$ and the supernatant was used as source of enzyme. Phosphatase activity was determined by Tabatabai and Bermner (1969) method and was expressed in $\mu$ moles PNP released $/ \mathrm{h} / \mathrm{g}$ fresh weight.

\section{Statistical analysis}

Statistical analyses were carried out using MSTAT-C program version 2.10 (1991). Least significant difference (LSD) was employed to test for significant difference at $\mathrm{P} \leq 0.05$ (Gomez and Gomez, 1984).

\section{Results and Discussion}

Mycorrhizal dependency (MD)

Mycorrhizal symbiosis is key component in helping the plants to cope with adverse environmental conditions. Under, heavy metals stress, biomass declined in non-mycorrhizal plants compared with the control. On the other hand, VAM plants grown in non-polluted and polluted soil showed a higher shoot and root dry weight than non-mycorrhizal plants (Table 1).

In this study, the value of mycorrhizal dependency clearly not affected by heavy metals stress (Table 1). This finding agree with Burleigh, et al. (2003) and Wang et al., (2006), who suggested that microsymbioses application may play an intelligible main role in the synergistic interactions. This may be a sign showing the ecological importance of VAM association for plant survival and growth under heavy metals stress. We suggest that improved growth and nutrient uptake by mycorrhizal plants are an indication of enhance the tolerance to heavy metals, compared with the non-mycorrhizal plants.

\section{Photosynthetic pigments}

As shown in Table 2, the chl.a, chl. b and carotenoid contents was significantly increased in mycorrhizal maize plants compared with non mycorrhizal ones. The results also showed a progressive decrease in chl. a, chl. b and carotenoid contents in maize plants grown under heavy metals. These results agree with the results recorded by Elahi et al., (2010).

Egypt. J. Bot., Vol. 55, No. 2 (2015) 
TABLE 1. Effect of heavy metals (Cd \& Pb) on biomass and Mycorrhizal dependency (MD) of maize plants inoculated with VAM fungal, grown at different concentration of $\mathbf{C d}$ or $\mathbf{P b}$.

\begin{tabular}{|c|c|c|c|c|}
\hline $\begin{array}{l}\text { Treatments } \\
(\mathrm{mg} / \mathrm{kg})\end{array}$ & & $\begin{array}{l}\text { Shoot dry } \\
\text { Wt. (g) }\end{array}$ & $\begin{array}{l}\text { Root dry } \\
\text { Wt. (g) }\end{array}$ & MD\% \\
\hline \multirow{2}{*}{ Control } & NM & $2.27 \mathrm{~b}$ & $5.52 \mathrm{~b}$ & \multirow{2}{*}{106.9} \\
\hline & $\mathrm{M}$ & $2.45 a$ & $5.88 \mathrm{a}$ & \\
\hline \multirow{2}{*}{$\mathrm{Cd} 25$} & NM & $1.99 \mathrm{bc}$ & $4.46 c$ & \multirow{2}{*}{114.57} \\
\hline & $M$ & $2.09 \mathrm{~b}$ & $5.03 b c$ & \\
\hline \multirow{2}{*}{$\mathrm{Cd} 100$} & NM & $1.29 \mathrm{e}$ & $3.75 d$ & \multirow{2}{*}{107.14} \\
\hline & $\mathrm{M}$ & $1.52 \mathrm{~d}$ & $3.88 \mathrm{~d}$ & \\
\hline \multirow{2}{*}{$\mathrm{Pb} 100$} & NM & $1.62 \mathrm{~d}$ & $4.01 \mathrm{~d}$ & \multirow{2}{*}{111.19} \\
\hline & $\mathrm{M}$ & $1.72 \mathrm{c}$ & $4.54 \mathrm{c}$ & \\
\hline \multirow{2}{*}{$\mathrm{Pb} 1000$} & NM & $1.13 \mathrm{e}$ & $3.59 \mathrm{e}$ & \multirow{2}{*}{111.01} \\
\hline & M & $1.46 \mathrm{~d}$ & $3.78 \mathrm{~d}$ & \\
\hline \multicolumn{2}{|c|}{ LSD 0.05} & 0.18 & 0.36 & \\
\hline
\end{tabular}

Different letters within the same column indicate a significant difference. $\mathrm{n}=3$.

TABLE 2. Photosynthetic pigment, total soluble protein and total soluble carbohydrates contents, in the leaves of non-inoculated or inoculated maize plants with VAM fungal grown at different concentrations of $\mathrm{Cd}$ or $\mathbf{P b}$.

\begin{tabular}{|c|c|c|c|c|c|c|}
\hline \multicolumn{2}{|c|}{$\begin{array}{c}\text { Treatments } \\
(\mathrm{mg} / \mathrm{kg})\end{array}$} & $\begin{array}{c}\text { Chl.a } \\
\text { mg/g fw }\end{array}$ & $\begin{array}{c}\text { Chl. b } \\
\text { mg/g fw }\end{array}$ & $\begin{array}{c}\text { Carotenoid } \\
\mathrm{mg} / \mathrm{g} \text { f w }\end{array}$ & $\begin{array}{c}\text { Soluble } \\
\text { carbohydrates } \\
\text { content } \\
(\mu \mathrm{g} / \mathrm{g} \mathrm{dw})\end{array}$ & $\begin{array}{l}\text { Soluble } \\
\text { protein } \\
\text { content } \\
(\mathrm{mg} / \mathrm{g} \mathrm{dw})\end{array}$ \\
\hline \multirow{2}{*}{ Control } & $\mathrm{NM}$ & $2.378 \mathrm{~b}$ & $0.960 \mathrm{~b}$ & $1.457 \mathrm{~b}$ & $779.65 b$ & $19.45 b$ \\
\hline & M & $2.599 a$ & $1.438 \mathrm{a}$ & $1.892 \mathrm{a}$ & $879.31 \mathrm{a}$ & $21.09 \mathrm{a}$ \\
\hline \multirow{2}{*}{$\mathrm{Cd} 25$} & $\mathrm{NM}$ & $1.898 \mathrm{~d}$ & $0.831 \mathrm{~d}$ & $1.143 \mathrm{~d}$ & $643.45 \mathrm{~d}$ & $15.20 \mathrm{e}$ \\
\hline & M & $1.982 \mathrm{c}$ & $0.870 \mathrm{c}$ & $1.200 \mathrm{e}$ & $694.45 c$ & $17.07 \mathrm{c}$ \\
\hline \multirow{2}{*}{ Cd 100} & $\mathrm{NM}$ & $1.603 \mathrm{f}$ & $0.731 \mathrm{~g}$ & $0.990 \mathrm{f}$ & $484.83 \mathrm{~g}$ & $11.79 \mathrm{~g}$ \\
\hline & M & $1.721 \mathrm{~g}$ & $0.784 \mathrm{f}$ & $1.030 \mathrm{~g}$ & $504.02 \mathrm{f}$ & $13.31 \mathrm{f}$ \\
\hline \multirow{2}{*}{$\mathrm{Pb} 100$} & $\mathrm{NM}$ & $1.624 \mathrm{~g}$ & $0.725 \mathrm{~g}$ & $1.035 \mathrm{c}$ & $566.21 \mathrm{e}$ & $13.89 \mathrm{e}$ \\
\hline & M & $1.754 \mathrm{c}$ & $0.804 \mathrm{c}$ & $1.148 \mathrm{~d}$ & $641.42 d$ & $16.06 \mathrm{~d}$ \\
\hline \multirow{2}{*}{$\mathrm{Pb} 1000$} & $\mathrm{NM}$ & $1.344 \mathrm{j}$ & $0.598 \mathrm{i}$ & $0.839 \mathrm{~h}$ & $413.79 \mathrm{i}$ & $8.78 \mathrm{i}$ \\
\hline & M & $1.561 \mathrm{~h}$ & $0.663 \mathrm{~h}$ & $0.891 \mathrm{~g}$ & $438.62 \mathrm{~h}$ & $11.16 \mathrm{~h}$ \\
\hline $\begin{array}{l}\text { LSD } \\
0.05\end{array}$ & & 0.003 & 0.006 & 0.008 & 6.67 & 0.51 \\
\hline
\end{tabular}

Different letters within the same column indicate a significant difference, $\mathrm{n}=3$.

Egypt. J. Bot., Vol. 55, No. 2 (2015) 
In addition the decline in chl. content in plants due to $\mathrm{Cd}$ and $\mathrm{Pb}$ stress a result of inhibition of important enzymes, such as $\delta$-aminolevulinic acid dehydratase and impairment in the supply of $\mathrm{Mg}^{2+}, \mathrm{Fe}^{2+}$ and $\mathrm{zn}^{2+}$ (Van Assche and Clijsters, 1990). The carotenoids act as light-harvesting pigments, and can protect chlorophyll and chloroplast membrane destruction by quenching triplet Chlorophyll and removing oxygen from excited Chl. oxygen complex (Young, 1991). It seemed that the enhancement of photosynthetic pigments contents in mycorrhizal plants can be attributed to the increase of absorption and translocation of essential ions which in turn accelerate the metabolic rates related to the biosynthesis of such contents.

\section{Total soluble carbohydrates}

Results recorded significant increase in soluble carbohydrate content in inoculated plants compared to non-inoculated ones (Table 2). This was in line with the results of Meenakshisundaram and Santhagura (2010) who's stated that VAM fungal inoculation induced an increase in soluble carbohydrate in Sorghum bicolor compared to non-inoculated control. This increment was correlated with the increase in Chl. contents; ameliorate the photosynthetic rate and nutrient uptake.

\section{Total soluble protein}

In this investigation, the total soluble protein content was significantly decreased with increasing the heavy metal $(\mathrm{Cd}$ or $\mathrm{Pb}$ ) concentrations (Table 2). VAM inoculation increased significantly the total soluble protein content regardless of heavy metal levels. At low $\mathrm{Cd}$ concentration, the total protein increase by $18.88 \%$, while at high concentration increased by $12.89 \%$ compared with non mycorrhizal plant grown at the same level. Same trends were recorded with $\mathrm{Pb}$ application. This could be due to their interference with the enzymes activities, which essential for normal metabolic and developmental processes as well as due to their direct interactions with proteins, pigments and carbohydrates (Bertrand and Guary, 2002). Based on these results and other results was early published for our group, the mechanisms related to physiological interactions between VAM fungi and maize plants involved in the increase of protein synthesis as well as induction of antioxidant enzymes to avoid heavy metal mediated oxidative stress (Rabie et al., 2013). Additionally, VAM fungi may be can detoxify the heavy metals via exudation of metal-binding proteins (Howe et al., 1997).

\section{Phosphorus and nitrogen contents}

Generally, the results recorded a marked increase in $\mathrm{P}$ and $\mathrm{N}$ contents in VAM inoculated maize plants compared to the non-inoculated ones (Table 3 ). Although the results revealed that heavy metals $(\mathrm{Pb}$ or $\mathrm{Cd})$ reduce the uptake and transportation of both nutrients in plants as also found by Godbold and Kettner, (1991). This increase in P content in inoculated maize plant may be due to the fast movement of this nutrient element into mycorrhizal hyphae and to increase the phosphatase activities in inoculated maize, which directly affect its content in leaves of mycorrhizal inoculated plants. This coincides with a finding by Ghani, (2010). 
The results revealed also an increase of $\mathrm{N}$ content in inoculated plants was concurred with Olesniewicz and Thomas, (1999), who's reported that VAM fungi enhanced $\mathrm{N}_{2}$-fixation by increasing root biomass, root- $\mathrm{N}$ absorption rates and finally the plant $\mathrm{N}$ contents. It seemed that the foliar $\mathrm{N}$ and $\mathrm{P}$ contents of inoculated maize plants reaffirms the key role of VAM fungi sustaining the plant cover in nutrient under heavy metals stress (Carrasco et al., 2011).

TABLE 3. Phosphorus and nitrogen contents in the leaves of non-inoculated or inoculated maize plants with VAM fungal grown at different concentrations of $\mathbf{C d}$ or $\mathbf{P b}$.

\begin{tabular}{|c|c|c|c|c|c|c|c|}
\hline \multirow{2}{*}{\multicolumn{2}{|c|}{$\begin{array}{c}\text { Treatments } \\
\text { (mg/kg) }\end{array}$}} & \multicolumn{3}{|c|}{$P$ content (ppm) } & \multicolumn{3}{|c|}{ N content (ppm) } \\
\hline & & \multirow{2}{*}{\begin{tabular}{|c|}
$\mathbf{3}$ \\
Weeks \\
$63.10 \mathrm{~b}$ \\
\end{tabular}} & \multirow{2}{*}{$\begin{array}{c}\begin{array}{c}6 \\
\text { weeks }\end{array} \\
100.6 \mathrm{~b} \\
\end{array}$} & \multirow{2}{*}{$\begin{array}{c}\begin{array}{c}9 \\
\text { weeks }\end{array} \\
141.0 \mathrm{~b} \\
\end{array}$} & \multirow{2}{*}{$\begin{array}{c}\mathbf{3} \\
\text { Weeks } \\
1.640 \mathrm{~b} \\
\end{array}$} & \multirow{2}{*}{$\begin{array}{c}\begin{array}{c}\mathbf{6} \\
\text { weeks }\end{array} \\
2.35 b\end{array}$} & \multirow{2}{*}{$\begin{array}{c}\mathbf{9} \\
\text { Weeks } \\
2.230 \mathrm{~b} \\
\end{array}$} \\
\hline & NM & & & & & & \\
\hline Control & $\mathrm{M}$ & $65.60 \mathrm{a}$ & $108.8 \mathrm{a}$ & $150.2 \mathrm{a}$ & $1.750 \mathrm{a}$ & $2.50 \mathrm{a}$ & $4.18 \mathrm{a}$ \\
\hline \multirow{2}{*}{$\mathrm{Cd} 25$} & NM & $54.80 \mathrm{~d}$ & $86.70 \mathrm{~d}$ & $126.0 \mathrm{e}$ & $1.360 \mathrm{e}$ & $1.93 \mathrm{e}$ & $2.31 \mathrm{e}$ \\
\hline & $\mathrm{M}$ & $59.20 \mathrm{c}$ & $97.60 \mathrm{c}$ & $139.0 \mathrm{c}$ & $1.57 \mathrm{c}$ & $2.29 \mathrm{c}$ & $2.50 \mathrm{c}$ \\
\hline \multirow{2}{*}{$\mathrm{Cd} 100$} & NM & $40.00 \mathrm{f}$ & $65.90 \mathrm{~g}$ & $97.00 \mathrm{i}$ & $1.00 \mathrm{~h}$ & $1.64 \mathrm{~h}$ & $2.03 \mathrm{~g}$ \\
\hline & $\mathrm{M}$ & $45.80 \mathrm{e}$ & $86.40 \mathrm{~d}$ & $108.4 \mathrm{~g}$ & $1.140 \mathrm{~g}$ & $1.860 \mathrm{f}$ & $2.290 \mathrm{e}$ \\
\hline \multirow{2}{*}{$\mathrm{Pb} 100$} & NM & $46.40 \mathrm{e}$ & $78.40 \mathrm{e}$ & $116.4 \mathrm{f}$ & $1.290 \mathrm{f}$ & $1.860 \mathrm{f}$ & $2.150 \mathrm{f}$ \\
\hline & M & $55.20 \mathrm{~d}$ & $86.80 \mathrm{~d}$ & $128.4 \mathrm{~d}$ & $1.430 \mathrm{~d}$ & $2.07 \mathrm{~d}$ & $2.430 \mathrm{~d}$ \\
\hline \multirow{2}{*}{$\mathrm{Pb} 1000$} & NM & $18.20 \mathrm{~h}$ & $62.40 \mathrm{~h}$ & $84.40 \mathrm{j}$ & $0.930 \mathrm{i}$ & $1.570 \mathrm{i}$ & $1.860 \mathrm{~h}$ \\
\hline & $\mathrm{M}$ & $25.60 \mathrm{~g}$ & $69.10 \mathrm{f}$ & $98.80 \mathrm{~h}$ & $1.00 \mathrm{~h}$ & $1.79 \mathrm{~g}$ & $2.05 \mathrm{~g}$ \\
\hline \multicolumn{2}{|c|}{ LSD 0.05} & 1.148 & 1.02 & 0.78 & 0.066 & 0.044 & 0.084 \\
\hline
\end{tabular}

Different letters within the same column indicate a significant difference, $n=3$.

\section{Phosphatase activity}

In this study it was observed that the activities of alkaline (ALP) and acid phosphatase (ACP) were significantly increased in inoculated maize plants grown in both contaminated and non-contaminated soil in compared to the noninoculated plants (Table 4). Concerning to mycorrhizal plants grown at high $\mathrm{Cd}$ concentration, ACP activity was $0.120,0.278$ and $0.398 \mu$ mole PNP after the three growth periods (3, 6 and 9 weeks) respectively. While at low $\mathrm{Cd}$ concentration activity was $0.165,0.350$ and $0.470 \mu$ mole PNP. Similar trend was obtained with $\mathrm{Pb}$ application. Although the results recorded significant increase in the activity of ALP in inoculated plants grown at low Cd concentration was $27.14 \%$, while at high $\mathrm{Cd}$ concentration was $42.08 \%$ in comparison with noninoculated plants grown at the same concentrations after 9 weeks from planting. In addition, it has been observed that the inhibition of phosphatase activity depends on these concentrations (Zheng, et al., 2009). This increment in phosphatase activities with the time of growth in inoculated plants led to increase in phosphate translocation to leaves (Selvaraj, 1998; Ezawa et al., 2001). Fries et al., (1998) showed the considerable increase in ACP and ALP activities in maize roots were closely correlated with the levels of VAM colonization in roots. Such response has also been observed by Tsckova and Galabova, (2003) in other inoculated plants under heavy metals stress and they suggested the inoculation as a possible process of detoxification and resistance which in divergent with the present results.

Egypt. J. Bot., Vol. 55, No. 2 (2015) 
ROLE OF VESICULAR ARBUSCULAR MYCORRHIZAL INOCULATION ... 303

TABLE 4. Acid (ACP) and alkaline phosphatase (ALP) activities of non-inoculated (NM) or inoculated (M) maize plants with VAM grown on heavy metals $(\mathrm{Cd}$ or $\mathrm{Pb})$ concentrations.

\begin{tabular}{|c|c|c|c|c|c|c|c|}
\hline \multirow[b]{2}{*}{$\begin{array}{c}\text { Treatments } \\
(\mathrm{mg} / \mathrm{kg})\end{array}$} & & \multicolumn{2}{|c|}{3 week } & \multicolumn{2}{|c|}{6 weeks } & \multicolumn{2}{|c|}{9 weeks } \\
\hline & & $\begin{array}{c}\text { ACP } \\
(\mu \mathrm{mole} \\
\mathrm{PNP} / \mathrm{h} / \\
\mathrm{g} \text { fw }) \\
\end{array}$ & \begin{tabular}{|c} 
ALP \\
$(\mu \mathrm{mole}$ \\
PNP/h/ \\
$\mathrm{g}$ fw $)$ \\
\end{tabular} & $\begin{array}{c}\text { ACP } \\
(\mu \mathrm{mole} \\
\mathrm{PNP} / \mathrm{h} / \mathrm{g} \\
\mathrm{fw}) \\
\end{array}$ & $\begin{array}{c}\text { ALP } \\
(\mu \mathrm{mole} \\
\text { PNP/h/g } \\
\text { fw }) \\
\end{array}$ & $\begin{array}{c}\text { ACP } \\
(\mu \mathrm{mole} \\
\mathrm{PNP} / \mathrm{h} / \mathrm{g} \\
\text { fw }) \\
\end{array}$ & $\begin{array}{c}\text { ALP } \\
(\mu \mathrm{mole} \\
\text { PNP/h/g } \\
\text { fw }) \\
\end{array}$ \\
\hline \multirow{2}{*}{ Control } & NM & $0.140 \mathrm{c}$ & $0.105 \mathrm{c}$ & $0.288 \mathrm{~d}$ & $0.218 \mathrm{c}$ & $0.396 \mathrm{~d}$ & $0.344 \mathrm{c}$ \\
\hline & M & $0.223 a$ & $0.134 \mathrm{a}$ & $0.396 \mathrm{a}$ & $0.307 \mathrm{a}$ & $0.537 \mathrm{a}$ & $0.424 \mathrm{a}$ \\
\hline \multirow{2}{*}{$\mathrm{Cd} 25$} & $\mathrm{NM}$ & $0.118 \mathrm{e}$ & $0.087 \mathrm{e}$ & $0.259 \mathrm{f}$ & $0.157 \mathrm{~g}$ & $0.357 \mathrm{e}$ & $0.291 \mathrm{e}$ \\
\hline & $M$ & $0.165 b$ & $0.124 b$ & $0.350 \mathrm{~b}$ & $0.263 b$ & $0.470 \mathrm{~b}$ & $0.370 \mathrm{~b}$ \\
\hline \multirow{2}{*}{$\mathrm{Cd} 100$} & NM & $0.109 \mathrm{f}$ & $0.056 \mathrm{~h}$ & $0.239 \mathrm{~h}$ & $0.115 \mathrm{i}$ & $0.309 \mathrm{~g}$ & $0.221 \mathrm{~h}$ \\
\hline & $\mathrm{M}$ & $0.120 \mathrm{e}$ & $0.092 \mathrm{de}$ & $0.278 \mathrm{e}$ & $0.208 \mathrm{~d}$ & $0.398 \mathrm{~d}$ & $0.314 d$ \\
\hline \multirow{2}{*}{$\mathrm{Pb} 100$} & $\mathrm{NM}$ & $0.108 \mathrm{f}$ & $0.064 \mathrm{~g}$ & $0.218 \mathrm{i}$ & $0.131 \mathrm{~h}$ & $0.338 \mathrm{f}$ & $0.251 \mathrm{~g}$ \\
\hline & M & $0.133 \mathrm{~d}$ & $0.096 \mathrm{~d}$ & $0.306 \mathrm{c}$ & $0.199 \mathrm{e}$ & $0.426 \mathrm{c}$ & $0.352 \mathrm{c}$ \\
\hline \multirow{2}{*}{ Pb1000 } & NM & $0.096 \mathrm{~g}$ & $0.034 \mathrm{i}$ & $0.216 \mathrm{j}$ & $0.110 \mathrm{i}$ & $0.312 \mathrm{~g}$ & $0.216 \mathrm{~h}$ \\
\hline & M & $0.108 \mathrm{f}$ & $0.077 \mathrm{f}$ & $0.247 \mathrm{~g}$ & $0.173 f$ & $0.386 \mathrm{~d}$ & $0.277 \mathrm{f}$ \\
\hline \multicolumn{2}{|c|}{ LSD 0.05} & 0.005 & 0.005 & 0.008 & 0.008 & 0.011 & 0.009 \\
\hline
\end{tabular}

Different letters within the same column indicate a significant difference, $\mathrm{n}=3$.

\section{Conclusion}

In conclusion, the results recorded that the vesicular-arbuscular mycorrhiza (VAM) alleviates the detrimental effect of heavy metals through improved the phosphatase activities and the nutrients uptake include $P$. This result indicates that the effect of VAM fungi on phosphorus uptake constitutes one of the main mechanisms for increasing plant adaptation to heavy metals. These physiological changes may be correlated to the enhancement of the rate of biosynthesis of some molecules in mycorrhizal plants like photosynthetic pigments, protein and carbohydrates.

\section{References}

Adriano, D. C., (2001) "Trace Elements in Terrestrial Environments; Biochemistry Bioavailability and Metals". Springer-Verlag, New York, pp., 150-159.

Bertrand, M. and J. C. Guary, (2002) How plants adopt their physiology to an excess of metals. In:"Handbook of Plant and Crop Physiology". Pessarakli M, Ed $2^{\text {nd }}$ ed. New York; Marcel Dekker, 751-761.

Burleigh, S. H., B. K. Kristensen and I. E. Bechmann, (2003) A plasma membrane zinc transport from Medicagotruncatula is up regulated in roots by fertilization, yet downregulated by arbuscular mycorrhizal colonization Plant Mol. Biol., 52(5):1077-1088. 
Carrasco, L., A. Azcon, A. Kohler, A. Roldan and F. Caravaca, (2011) Comparative filamentous and arbuscular mycorrhizal fungi in the establishment of an autochthonous, leguminous shrub growing in a metal-contaminated soil. Sci. total Environ., 409: 1205-1209.

Clemens, S. (2001) Molecular mechanism of plant metal tolerance and homeostasis Planta, 212: 475-486.

Elahi, F. E., Mridha, M. A. and Aminuzzaman, D. (2010) Influence of AMF inoculation on growth, nutrient uptake, arsenic toxicity and chlorophyll content of eggplant grown in arsenic amended soil. Advan Natural Appl Sci., 4(2): 184-192.

Ezawa, T.S., Smith, E. and Smith, F.A. (2001) Differentiation of polyphosphate metabolism between the extra and intraradical hyphae of arbuscular mycorrhizal fungi, New Phytol., 149: 555-563.

Fries, L.L., Pacovsky, R.S. , Safir, G. R. and Kaminski, J. (1998) Phosphorus effect on phosphatase activity in endomycorrhizal fungi associated with maize. Physiol. Plant, 103: $152-171$.

Gerdemann, J. W., (1975) Vesicular arbuscular mycorrhizal. In: "The Development and Function of Roots". D.G. Torrey and D. T.C Clarkson, (Eds). Academic press, London pp:575-591.

Gerdemann, J. W. and Nicolson, T. H., (1963) Spores of mycorrhizal endogen species extracted from soil by wet sieving and decanting. Trans. Br. Mycol. Soc., 46: 235-244.

Ghani, A., (2010) Toxic effect of heavy metals on plant growth and metals accumulation in Maize (Zea mays L.). Iranian J. Toxicology, 3(3):325-334.

Godbold, D. L. and Kettner, C. (1991) Lead influences root growth mineral nutrition of Picea abies seedlings. J. Plant Physiol., 139: 95-99.

Gomez, K. a. and Gomez, A.A. (1984) "Statistical Procedures for Agricultural Research", Lviley. Interscience Publication, New York, P. 678.

Hall, J. L. (2002) Cellular mechanism of heavy detoxification and tolerance. J. Exp. Bo, 53(366): 1-11.

Howe, R., Evans, R.L. and Ketteridge, S.W. (1997) Copper-binding protein in ectomycorrhizal fungi. New Phytologist, 135 (1): 123-131.

Jackson, M. L., (1958) "Soil Chemical Analysis". Englewood Cliffs, NJ; Prentice-Hall.

Jackson, M. L., (1973) "Soil Chemical Analysis Prentice Hall of Indian Ltd"., New Delhi, 574pp.

Lowry, O. H., Rosbrough, N. J. and Randall, R. J. (1951) Protein measurement with Folin phenol reagent. J Biol Chem., 193: 265-275.

Meenakshisundaram, M. and Santhaguru, K. (2010) Studies on association of arbuscular mycorrhizal fungi with Gluconacetobacter diazotrophicus and its effect on improvement of Sorghum bicolor (L.). Asian J. Exp. Biol Sci., 1(4): 855-863.

Egypt. J. Bot., Vol. 55, No. 2 (2015) 
ROLE OF VESICULAR ARBUSCULAR MYCORRHIZAL INOCULATION ... 305

Metzner, H., Ran, H. and Senger, H. (1965) Unnter suchzur syndronisier barkarbeir einzelener-pigment, MangelMutanten von Chorella. Plant, 65:186-194.

Olesniewicz, K. S. and R. Thomas, B. (1999) Effects of mycorrhizal colonization on biomass production and nitrogen fixation of black locust (Robinia pscdoacacia) seedlings grown under elevated atmospheric carbon dioxide. New Phytol., 142: 133-140.

Rabie, G.H., A, shaltout, M., Shaaban, L. D. and Metwally, R. A. (2013) Evaluation of vesicular mycorrhizal fungi effects on growth and heavy metals uptake by maize plants. Egyt. J. Bot. $3^{\text {rh }} 321-335$.

Said, A. and Naguib, M. (1964) Sucrose determination as a mean of estimation the drawback tax Halawa Tehinia. Bull. Fac. Sci., Cairo Univ., 39: 207-216.

Selvaraj, T., (1998) Studies on mycorrhizal and rhizobial symbioses on tolerance of tannery effluent treated Prosopis juliflora, Ph. D. Thesis, University of Madras, Chennai, India, 209.

Sieverding, E., (1991) Vesicular-arbuscular mycorrhiza management in tropical agrosystems. "Technical Cooperation, Federal Republic of Germany Eschborm", ISBN 3-8085-462.

Tabatabai, M. A. and Bermner, J. K. (1969) Use of $P$-nitrophenyl phosphate for assay of soil phosphatase activity. Soil Biol. Biochem., 1: 301-307.

Tamboli, M. and Vyas, A. (2012) Mycorrhizal at polluted site of western Rajasthan. Int. J. Plant, Animal and Environ. Sci., 2(4): 206-212.

Tsckova, K. and Galabova, D. (2003) Phosphatase production and activity in copper (II) accumulation Rhizopus delemar. Enzyme and microbial Technology, 33 (7): $\quad 926-$ 931.

Van Assche, F. and Clijsters, H. (1990) Effect of metals on enzyme activity in plants. Plant Cell Enviro., 13:195-206.

Wang, F., Lin, X., Yin, R. and Wu, L. (2006) Effect of arbuscular mycorrhizal inoculation on the growth of Elsholtzia splendes and Zea mays and activities of phosphatase and urease in a multi-metal-contaminated soil under unsterilized conditions. Applied soil Ecology, 31:110-119.

Young, A. J., (1991) "Inhibition of Carotenoid Biosynthesis". Eds. N. R. Baker and M. P. Percival Herbicides. Elsevier Publishers, PP:131-171.

Zafar, S. A., F. quil and I. Ahmad, (2007) Metal tolerance and biosorption potential of filamentous fungi isolated from metal contaminated agricultural soil. Bioresource Technol., 98: 2557-2561.

Zheng, W., Fei Y. and Huang, Y. (2009) Soluble protein and acid fungi and seedlings in response to excessive Cu and Cd. J. Enviorn. Sci., 21: 1667-16672.

(Received 5 /1/2015;

accepted $12 / 4 / 2015)$ 


\section{دور فطريـات الميكـوريزا في تحسين تحمـل نبـات الـذرة الثـاميه ل العناصر الثقيلة. \\ 'لميس دسوقي شعبان' ،جمال حسن ربيع'، رباب عنترمتولي,'

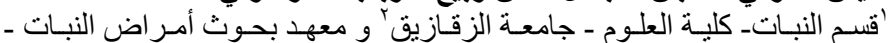 \\ مركز البحوث الزراعية.}

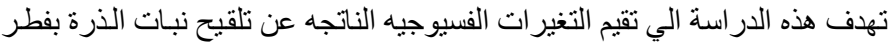

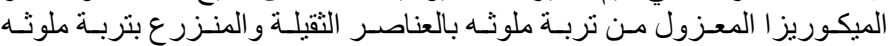

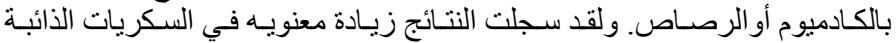

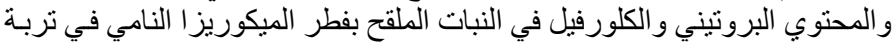

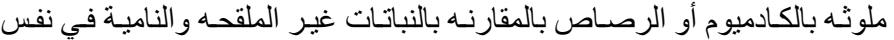

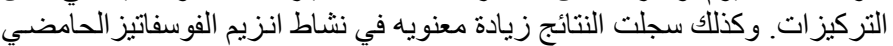

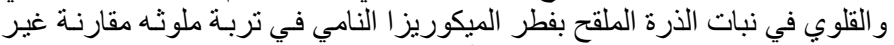

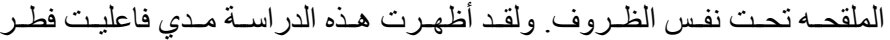

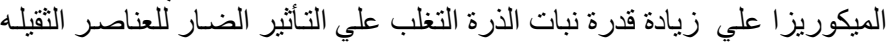

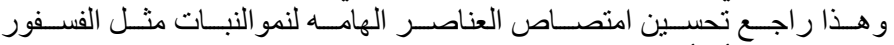

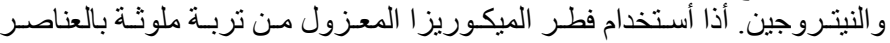
الثقيلة يعتبر تكنيك ناجح يعمل علي تحسين تحمل النبات لهذه العناصر. 